\title{
Berlin 1995
}

\author{
By Gerald Pratley
}

Fall 1995 Issue of KINEMA

IF IT WAS SAID ONCE it was said a hundred times: "The cinema was invented a hundred years ago but today's filmmakers don't know how to make movies. After a century of existence they are rapidly going backwards."

A sweeping statement and fortunately, there are exceptions, but this was the consensus at the conclusion of the showing of the Competition films at Berlin's 45th International Film Festival. By general agreement this year's festival has not matched up to last year's standards which were themselves lower than the year before. All of which leads to the questions frequently asked among the ranks of the media - is this the best that Moritz de Hadeln could find? Is Cannes proving to be a continuing stumbling block to obtaining the best entries? Or is he losing his sense of judgment after 15 years in charge?

The film expected to win the Golden Bear was Wayne Wang's Smoke with Harvey Keitel, a garrulous comedy set in Brooklyn and introducing a stream of eccentric characters most of whom we have seen in other films but never in such full force as this. The Jury decided differently however and much to everyone's surprise gave the Award deservedly to Bertrand Tavernier's L'Appât (The Bait) a searing, gripping account of adolescents on the murder trail in Paris, based on actual events. This is not just another horrifying picture of crime; Tavernier uses it to create a thought-provoking study of young people deluged by the artificiality of the "good life" as it pours forth in a constant flow of images from video, TV, and movie screens, in advertising and commerce. Appearance, society is constantly being told, is all that matters.

Smoke had to be content with the FIPRESCI Award for a Competition entry. This organisation of international critics gave its Panorama Prize to Antonia Bird's controversial Priest, its Forum Prize to Citizen Langlois, and a Special Mention to Tokyo Kyodai.

Canada's entries were led by Patricia Rozema's When Night is Falling, in Competition, with Pascale Bussières, Rachael Crawford and Henry Czerny. The word had spread that this story of two women, one a devout Christian and the other a circus performer, who fall in love, was a steamy affair unlike any other! No matter how sophisticated festival participants believe themselves to be their baser instincts are always aroused at the thought of "steamy scenes" awaiting them.

The Congress Hall then, was packed and late arrivals sat in the aisles. The film, well photographed by Douglas Koch, proceeded; a dead dog is placed in a refrigerator, the actresses kissed now and then, but we had little sense of any moral struggle on the part of the woman of the church in attempting to come to terms with this important development in her life. Her lover Rachael Crawford, is the aggressive partner. The thought crossed our minds - does she, being black, represent a satanic force here? Not at all, denied the director later at her press conference, "Rachael happened to be the best actress for the role." There was one "making love in bed" sequence between Czerny, looking suitably bewildered, and his soon to be lost lover, and another between the two women. This was not overly-explicit. The camera showed body parts in dreamily edited close-ups leaving it to the audience to puzzle out what they were.

The Europeans loved the film, they cheered, applauded and wrote nice comments about it: the Americans, British and most Canadians, disliked it intensely: "bland," they said, "superficial, poorly written," "silly dialogue," "dull and passionless."

Patricia Rozema was happy however, and spoke eloquently about her work, her feelings, her Calvinistic fears, and answered the usual questions about the financing methods of Canada's funding agencies. Then came the dreaded question: "Are you a lesbian?" Referring to Barbara Tranter and Rachael Crawford who sat with her at the table, she brightly replied, "We live together and arrange our schedule accordingly." This brought on much needed laughter. She then confided that her next film might well be made from another writer's screenplay. Many present thought this a good idea. 
Lesbianism on the screen was almost everyday. The British Competition entry, Butterfly Kiss, directed by Michael Winterbottom, (Family) is a disturbing depiction of two mentally deranged young women, brilliantly played by Amanda Plummer and Saskia Reeves, who become lovers and take the road to murder. A religious ambiguity underlines their matter-of-fact behaviour, adding to its frightening reality. At their press conference they too were asked if they were lesbians. Saskia Reeves was clearly somewhat embarrassed and replied in the negative. Ms Plummer relished the question and said, yes, she had indeed tried it, found it wanting, but still thought it might have something to offer her.

Two other Canadian entries did well: Cynthia Roberts' and Greg Klymkiw's film of the Liitoja play, The Last Supper, about a young dancer dying of AIDS, with three players, Ken McDougall, Jack Nicholson and Daniel MacIvor, winning the Teddy Bear given by the festival's Gay and Lesbian Award group; and Mina Shum's Double Happiness won the Wolfgang Staudte Film Prize bringing her double happiness with $\$ 20,000$ in cash. All the filmmakers were present - together with Jeremy Podeswa, whose Eclipse was shown in the Forum section, and Kal Ng with The Soul Investigator - at the Telefilm party in the Film Centre, always one of the jolliest events at Berlin smoothly organised by Jean Lefebvre and Michelle Bischoff, ably assisted by the affable and busy Jim Murphy representing the OFDC.

Four German films were chosen for the Competition section. Opening night was given to Margarethe von Trotta's Das Versprechen (The Promise), a likeable and decent love story taking place during the time of the Wall; Die Nacht Der Regisseure (Night of the Filmmakers) by Edgar Reitz, a strange celebration of the 100th Anniversary of the Cinema composed entirely of digitalized images; Transatlantis by Christian Wagner (not a good word said of it), and Hades, written, directed and performed by "anarchist" Herbert Achternbusch, an absurd, satirical and critical work - depending on whom you listen to!

Compared to these four German entries there were seven American films. This brought on the expected torrent of criticism from European filmmakers and political figures protesting Hollywood's domination of European cinema. But the public didn't seem to care as it fought to get tickets to see them all, wept over the absence of Robert Redford and Paul Newman in person, and on the Ku'dam they lined up in the hundreds every night to see Forrest Gump. It is at times like this when the visitor from abroad sees the living evidence of the enormous power and influence Hollywood exerts over the movie-going public - not only in Germany of course, but around the world. The answer to this is simple; the people en masse everywhere like its pictures.

But as Berlin grows larger, as a city and a festival, money becomes more difficult to find. The generous subsidies that once made the former West Berlin the island of democracy within "the evil empire" have dried up. It is no more the island but just another city. So, as long as the crowds throng to the box office to see American films they will always find a place on the festival program. The art of the cinema has been relegated to the back seats. Once again the familiar observation was heard - there were better films "out of competition"; but they are not going to bring in the big money and festivals like Berlin now need even larger revenues than before. But even the crowd-pleasers are not enough: this year, as at Cannes last year, the commercial sponsor has appeared for the first time at Berlin to help ease the pain. Bitburger, the brewery, has its name discreetly on the screen and even provided free beer for the media. "Our aim," said the company, "in sponsoring the Film Festival is to demonstrate our interest in world-class events to the expected 250,000 visitors, the over 3,000 journalists and millions of readers and television viewers." But what did it get in return? Boos and hisses in the cinema when its symbol appeared on the screen. Is anyone ever satisfied?

\section{Author Information}

Gerald PRATLEY, OC, LLD, started his career as film critic with the CBC. In 1969, he founded the Ontario Film Institute which he directed until 1990. He has written several books and numerous articles on film, including Torn Sprockets, a history of Canadian cinema. He taught Film History in universities in Toronto and Waterloo, Canada and holds three honorary degrees from Canadian and US universities.

Gerald A. Pratley (1923-2011) was born and educated in London, England, and came to Canada in 1946. He started working in Toronto for the $\mathrm{CBC}$ as a scriptwriter. He was drawn toward working in motion pictures, and became, in 1948, the CBC's first film critic and commentator. 
Gerald Pratley broadcast three programmes a week, Pratley at the Movies, The Movie Scene, Music From the Films, and others, until 1975. During this time he also became the first post-war chairman of the Toronto Film Society, chairman of the Toronto and District Film Council and co-founder of the A-G-E Film Society and correspondent for international magazines such as Films and Filming, Film In Review, Variety, Hollywood Quarterly and International Film Guide. During the 1950s he wrote for Canadian Film Weekly and Canadian Film Digest.

He became known as a speaker on all aspects of motion picture art and industry, and was invited to teach film history at the University of Toronto, York University, University of Waterloo, Seneca College and Ryerson Polytechnical University, with individual lectures being given at many other Canadian and US universities and colleges. He has served as a member of various judging panels of competitions and festivals, being one of the members of the first Canadian Film Awards in 1949.

From 1970 to 1975 he was the director of the Stratford (Ontario) International Film Festival, and from 1969 to 1976 he was Chairman of the International Jury of the Canadian Film Awards. He has attended all the world's leading festivals of film, and in particular, for 30 years, the Cannes Festival as CBC correspondent. He has written six books, The Films of Frankenheimer: Forty Years in Film; The Cinema of John Frankenheimer; The Cinema of Otto Preminger; The Cinema of David Lean; The Cinema of John Huston, and Torn Sprockets, a history of the Canadian cinema.

Gerald Pratley has served on the Advisory Boards of the film departments of Ryerson Polytechnical University and Humber College, and as a member of the programme committee of TV Ontario. In 1968 he became the founder-director of the Ontario Film Institute of the Province of Ontario, an organization which has distinguished itself in archival holdings and public service and is known since 1990 as the Cinematheque of Ontario. He taught Film History courses at the Department of Film and Photography, Ryerson Polytechnic University, Toronto and the University of Waterloo.

In 1984, Gerald Pratley was made a Member of the Order of Canada and in 2003 Officer of the Order of Canada for his service to Canada through film appreciation. He holds Honorary Degrees in Letters and Fine Arts from York and Waterloo Universities (Ont., Canada) and Bowling Green State University (Ohio, USA).

In 2002, Gerald Pratley received a Special Genie Award from the Academy of Canadian Cinema \& Television in recognition of his lifelong dedication to the promotion and his exceptional support of Canadian cinema.

He died on 14 March 2011 in Ontario, Canada. 